\title{
Antioxidant and alpha-glucosidase inhibitory activities of Euchresta horsfieldii
}

\author{
AMALIA INDAH PRIHANTINI", KRISNAWATI, ALI SETYAYUDI \\ Research and Development Institute of Non-Timber Forest Product Technology, Research, Development, and Innovation Agency, \\ Ministry of Environment and Forestry of Indonesia. Jl. Dharma Bhakti No. 7, Langko, Lingsar, Lombok Barat, West Nusa Tenggara, Indonesia. \\ Tel.: +62-370-6175552, Fax.: +62-370-6175482, `email: amaliaindah2@gmail.com
}

Manuscript received: 8 January 2019. Revision accepted: 8 July 2019.

\begin{abstract}
Prihantini AI, Krisnawati, Setyayudi A. 2019. Antioxidant and alpha-glucosidase inhibitory activities of Euchresta horsfieldii. Biofarmasi J Nat Prod Biochem 17: 65-68. Euchresta horsfieldii, known as pranajiwa, is a medicinal plant widely grown in Bali and West Nusa Tenggara, Indonesia. Its seeds or fruits are commonly used for body freshness and stamina. The present study aimed to investigate the biological activities of leaves, roots, stems, fruits, and seeds of $E$. horsfieldii. Antioxidants, alpha-glucosidase inhibitory activities, and total phenolic compounds were evaluated from methanolic extracts of all parts of $E$. horsfieldii. The result showed that leaf extract of $E$. horsfieldii exhibited the highest antioxidant activity with $\mathrm{IC}_{50} 215.11 \pm 08.06 \mu \mathrm{g} / \mathrm{mL}$. Meanwhile, the root extract had the highest alpha-glucosidase inhibitory activity and total phenolic compound with $\mathrm{IC}_{50} 29.76 \pm 13.17 \mu \mathrm{g} / \mathrm{mL}$ and $763 \pm 0.01 \mathrm{mg}$ $\mathrm{GAE} / 100 \mathrm{mg}$ dry extract, respectively. In conclusion, the study suggested that $E$. horsfieldii is the potential as a natural source of antioxidant and alpha-glucosidase inhibitor agents.
\end{abstract}

Keywords: Alpha-glucosidase inhibitor, antioxidant, Euchresta horsfieldii, total phenolic content

\section{INTRODUCTION}

Free radicals, chemical compounds having one or more unpaired electrons, play a critical role in our health. They are highly unstable and can damage other molecules by extracting electrons in order to attain stability. Reactive oxygen species (ROS), the free radical generated from oxygen, initiate bimolecular oxidation and affect resultant DNA damage, protein carbonylation, and lipid peroxidation, which leads to cell death and creates oxidative stress such as cancer, cardiovascular disease, neurological disorder, arthritis, atherosclerosis as well as aging process (Khalaf et al. 2007; Pham-Huy et al. 2008; Chanda and Dave 2009; Piao et al. 2009). Antioxidants can help our body deal with oxidative stress caused by free radical-induced damage.

The high accumulation of ROS can also enhance the risk of diabetes ( $\mathrm{Ha}$ et al. 2008; Noh and $\mathrm{Ha}$ 2011). Diabetes mellitus is a condition defined by the level of hyperglycemia. Some reports suggest that decreasing the level of postprandial hyperglycemia is one of the most effective therapeutic approaches in the early period of diabetes mellitus (Lee et al. 2009; Ghadyale et al. 2011; Van de Laar et al. 2012). Other studies demonstrated that alpha-glucosidase inhibitors helped control postprandial blood glucose levels in diabetic patients (Sancheti et al. 2011; Gurudeeban et al. 2012).

Our nature is rich in potential compounds for drugs or medicines. In Indonesia, a medicinal plant is known as pranajiwa (Euchresta horsfieldii) grows in forests and is categorized as a threatened plant (Mogea et al. 2001). Its seeds and fruits have been traditionally used for stimulants, aphrodisiacs, refreshments, asthma, tuberculosis, cough, hyperlipidemia, etc. (Heyne 1987; Kloppenburgh 2006; Tirta et al. 2010; Kim et al. 2011). The seeds and fruits are produced as a traditional herbal drink called jamu and other products with high economic value. The leaf of $E$. horsfieldii has been reported to have antioxidant activity and increase enzyme activity of superoxide dismutase and glutathione peroxidase in Wistar rats (Tirta et al. 2010; Gunawan et al. 2017). However, fewer reports studied other parts of the plant and alpha-glucosidase inhibition activity as an approach for diabetes management. Therefore, the aim of the study was to evaluate the bioactive compounds, particularly antioxidants and alphaglucosidase inhibitory activities, from roots, stems, leaves, fruits, and seeds of E. horsfieldii. Furthermore, the total phenolic content of the extracts was also evaluated since they are considered to contribute as antioxidants or alphaglucosidase inhibitors.

\section{MATERIALS AND METHODS}

\section{Chemicals}

Quercetin, 1,1-diphenyl-2-picrylhydrazyl (DPPH), $p$ nitrophenyl- $\alpha$-D-glucopyranoside, and alpha-glucosidase were obtained from Wako Pure Chemical Industries Ltd., Osaka, Japan. Folin-Ciocalteu reagent was purchased from Sigma Aldrich, Japan. All the solvents used were at the highest purity available. 


\section{Extract preparation}

Approximately $10 \mathrm{~g}$ dried samples of roots, stems, leaves, fruits, and seeds of pranajiwa were extracted with distilled methanol. The extracts were filtered and concentrated under a rotary evaporator and then vacuumed and dried. The extraction was conducted twice to obtain approximately $1 \mathrm{~g}$ crude extract.

\section{DPPH radical scavenging activity assay}

The DPPH radical scavenging activity was conducted with minor modifications based on a previous method (Jayaprakasha et al. 2001). Various concentrations at 20, 50,100 , and $200 \mu \mathrm{g} / \mathrm{mL}$ of samples were mixed with 0.5 $\mathrm{mL}$ of methanol $1 \mathrm{mM}$ DPPH radical solution. A similar solution without a sample was used as a control. Absorbance was measured using a UV-vis spectrophotometer at $517 \mathrm{~nm}$ after incubation at room temperature under dark conditions for $30 \mathrm{~min}$. Quercetin was used as a positive standard. The following formula determined the percentage of scavenging activity: $100 \%$

Scavenging activity $(\%)=\left[\left(\mathrm{A}_{\text {control }}-\mathrm{A}_{\text {sample }}\right) / \mathrm{A}_{\text {control }}\right] \mathrm{x}$

\section{Alpha-glucosidase inhibition assay}

The alpha-glucosidase inhibitory activity of the crude extracts was evaluated using a method described by Dewi et al. (2014). The reaction mixture containing $5 \mu \mathrm{L}$ of the sample was dissolved in DMSO at various concentrations, and $495 \mu \mathrm{L}$ of $100 \mathrm{mM}$ phosphate buffer ( $\mathrm{pH}$ 7.0) was added to $250 \mu \mathrm{L}$ of $3 \mathrm{mM}$ substrate solution $p$-nitrophenyl$\alpha$-D-glucopyranoside (PNPG). The mixtures were preincubated for $5 \mathrm{~min}$ at $37^{\circ} \mathrm{C}$, and $250 \mu \mathrm{L}$ of alphaglucosidase $(0.065 \mathrm{unit} / \mathrm{mL})$ was added to start the reaction. The incubation was continued for $15 \mathrm{~min}$, and the reaction was terminated by adding $1 \mathrm{~mL}$ of $0.1 \mathrm{M}$ sodium carbonate. Alpha-glucosidase inhibitory activity was quantified by measuring the released product of $p$ nitrophenyl at $400 \mathrm{~nm}$. Quercetin was used as a positive standard.

\section{Total phenolic content}

The extracts' total phenolic content (TPC) was determined using the Folin-Ciocalteu reagent (Singleton et al. 1999). Approximately $500 \mu \mathrm{L}$ of the extracts $(1.0$ $\mathrm{mg} / \mathrm{mL}$ ) was added with distilled water, made up to $8 \mathrm{~mL}$, and then mixed with $500 \mu \mathrm{L}$ of $2 \mathrm{~N}$ Folin-Ciocalteu reagents. The mixture was allowed to stand for $8 \mathrm{~min}$, and $1.5 \mathrm{~mL}$ of $20 \%$ sodium carbonate was then added. The reaction mixture was incubated at room temperature for 2 h. Absorbance was measured at $765 \mathrm{~nm}$, and the phenolic content was determined using a calibration curve obtained from gallic acid.

\section{Statistical analysis}

All assays were performed in triplicates, and the data were expressed as the mean \pm standard deviation. Statistical analysis was carried out using SPSS version 16.0 for Windows, followed by Tukey`s post hoc test. Differences at $P<0.05$ were considered to be significant.

\section{RESULTS AND DISCUSSION}

\section{DPPH radical scavenging activity}

DPPH is a stable radical widely used to evaluate the activity of scavenging free radicals. Free radicals were reduced by antioxidants that donate their hydrogen (ElHaci et al. 2013). Therefore, DPPH radical scavenging assay is a common method for antioxidant evaluation. The discoloration measured the antioxidant activity to yellow as a stable molecule 2,2-diphenyl-1-hydrazine formed from purple solution as DPPH radicals in methanol. Activity on scavenging DPPH radical of the extracts of pranajiwa is shown in Figure 1. The dose-dependent activity is shown as an $\mathrm{IC}_{50}$ value reflecting the required concentration for $50 \%$ inhibition. A lower $\mathrm{IC}_{50}$ value represented higher antioxidant activity.

Leaves extract showed the highest activity, followed by roots and stem extracts with $\mathrm{IC}_{50}$ 215.11 \pm 8.06 , $266.18 \pm 13.17$, and $302.67 \pm 26.90 \mu \mathrm{g} / \mathrm{mL}$, respectively. Meanwhile, fruits and seeds extracts had a lower activity with $\mathrm{IC}_{50} \quad 462.7 \pm 38.32$ and $468.79 \pm 42.27 \mu \mathrm{g} / \mathrm{mL}$, respectively. Interestingly, besides fruits and seeds, which Indonesian people usually consume, the leaves revealed potency as a medicinal source. These results were supported by Sari et al. (2015), who reported that $n$-hexane leaves extract of pranajiwa had high antioxidant activity. Therefore, the antioxidant potency of its leaves can be considered for further utilization of herbal medicine.

The strength of antioxidant activity depends on the existence of various secondary metabolites (Emami et al. 2007). Some phenolic compounds, tannins, phenyl isopropanoids, lignans catechol, and many others are good antioxidants (Rice-Evans et al. 1996). Several essential oils have also been studied for their antioxidant activities (36). Variation in the amounts of various non-volatile and volatile compounds can be one of the reasons causing differences in the antioxidant activity of the extracts from different parts of the plant (Emami et al. 2007).

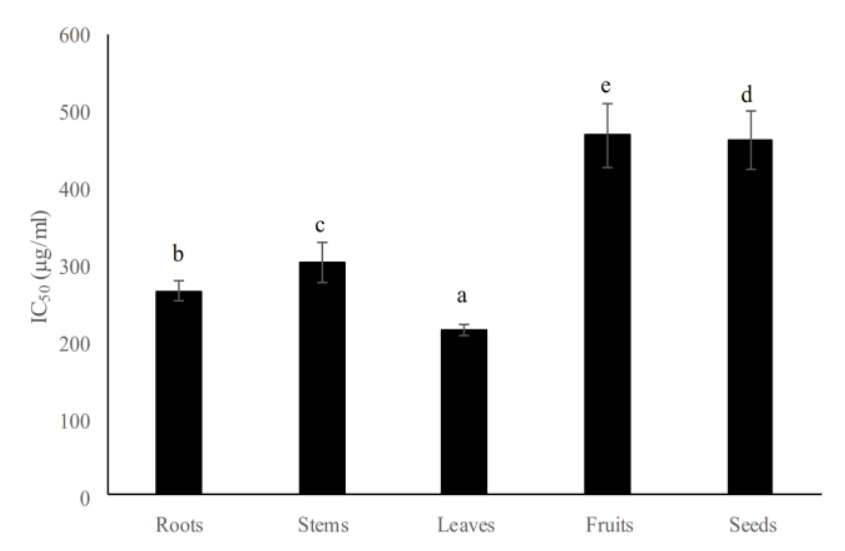

Figure 1. Antioxidant activity of pranajiwa (Euchresta horsfieldii) methanolic extracts 


\section{Alpha-glucosidase inhibitory activity}

The alpha-glucosidase inhibition assay can be related to the effort to search for alternative medicines, particularly for type 2 diabetes mellitus (DM). An approach to treat type $2 \mathrm{DM}$ is by reducing blood glucose levels in the body. Alpha-glucosidase is a catalyzing enzyme in the final digestion process of carbohydrates. The enzyme breaks down oligosaccharides and disaccharides into monosaccharides. Delaying absorption of carbohydrates is necessary for glycemic control (Cheng and Josse 2004). Inhibiting alpha-glucosidase activity retards the absorption of glucose (Ghadyale et al. 2011; Lee et al. 2009; Van de Laar et al. 2005). Therefore, the inhibition of alphaglucosidase activity can be used in diabetic management.

Alpha-glucosidase inhibitory activity of the extracts of pranajiwa is shown in Table 1. Roots extract had the highest activity against alpha-glucosidase, followed by stems extract with $\mathrm{IC}_{50} 29.76 \pm 3.76$ and $107.95 \pm 4.68 \mu \mathrm{g} / \mathrm{mL}$, respectively. Meanwhile, leaves, fruits, and seeds extract of pranajiwa did not show alpha-glucosidase inhibition. Roots extract, which showed high antioxidant activity and highest alpha-glucosidase inhibitory activity, revealed strong potency as a natural source of the anti-diabetes agent. It is due to that an ideal anti-diabetes treatment should possess both hypoglycemic and antioxidant properties (Shibano et al. 2008). It is also indicated that an antioxidant assay combined with an alpha-glucosidase inhibition assay is necessary to consider the potencies of the plant in diabetic treatment.

\section{Total phenolic content}

Phenolic compounds are commonly considered to play an important role in antioxidant and alpha-glucosidase inhibitory activities. Therefore, it is necessary to evaluate total phenolic content to support antioxidant and alphaglucosidase inhibition assays. The phenolics content was expressed in the percentage of the gallic acid equivalent (GAE). The evaluation of total phenolic content from various extracts of pranajiwa revealed that roots extract had the highest phenolic contents $(7.63 \pm 0.01 \%$ GAE/dry extract). On the other hand, leaves, stems, and seeds are slightly lower than roots extract $(7.63 \pm 0.01 ; 6.03 \pm 0.09$; $5.89 \pm 0.01$; and $4.09 \pm 0.11 \%$ GAE/dry extract), as shown in Table 2.

Phenolic compounds can donate their electron without becoming reactive radicals; therefore, they are considered good antioxidants. As the previous result showed that the leaves and stems had higher antioxidant activity, it implied that their phenolic contents contributed to the antioxidant activity. Due to the chemical structures of phenolics, they can stabilize unpaired electrons (Chanda and Dave 2009).

Roots extract showed the highest alpha-glucosidase inhibitory activity and higher antioxidant activity, indicating its high contribution of phenolic content. Meanwhile, an ideal anti-diabetes treatment should possess both antioxidant and hypoglycemic properties (Shibano et al. 2008). Therefore, the evaluation of antioxidants combined with alpha-glucosidase inhibition assays is an approach that can be considered a strategy for the management of diabetes. The free radicals generated from oxygen, reactive oxygen species (ROS), can cause excessive oxidation and affect diabetes (Basma et al. 2011; Meziti et al. 2012). ROS production increases under diabetic conditions (Noh and Ha 2011; Ha et al. 2008). Meanwhile, alpha-glucosidase inhibitors helped control postprandial blood glucose levels in diabetic patients (Sancheti et al. 2011; Gurudeeban et al. 2012). It reduces digestion and delays carbohydrate absorption, relieving the postprandial increase in blood glucose levels (Cheng and Josse 2004). Therefore, a root extract of pranajiwa showed potency as a source of the antidiabetic agent. However, further study on the isolation of the active compounds is required.

On the other hand, leaf extract did not become active against the alpha-glucosidase enzyme. Still, it revealed that antioxidant activity and total phenolic content were slightly lower than root extract. The result implied that the phenolics might contribute to antioxidant activity; however, there is less support for alpha-glucosidase inhibitory activities. It is considered that other secondary metabolites, such as alkaloids and terpenes, might play a role in alpha-glucosidase inhibitory activities, as reported by a previous study (Bahmani et al. 2014). In addition, antagonistic or synergetic interactions between secondary metabolites may have contributed to the activity (Prihantini et al. 2014; Bahmani et al. 2014).

In conclusion, the leaves, roots, and stems of pranajiwa had potency for antioxidants. Furthermore, the roots had the highest activity against alpha-glucosidase enzyme and total phenolic content. The study suggested that the leaves, roots, and stems of pranajiwa had high potency as a medicinal source. Therefore, the overexploitation of seeds or fruits of pranajiwa can be reduced. Studies on the isolation of the compounds responsible for the antioxidant and or alpha-glucosidase inhibitory activities of pranajiwa are warranted.

Table 1. Alpha-glucosidase inhibitory activity of pranajiwa extracts

\begin{tabular}{lc}
\hline Extracts & IC $_{\mathbf{5 0}}(\boldsymbol{\mu g} / \mathbf{m L})$ \\
\hline Roots & $29.76 \pm 3.76$ \\
Stems & $107.95 \pm 4.69$ \\
Leaves & n.a \\
Fruits & n.a \\
Seeds & n.a
\end{tabular}

Note: $\mathrm{n} . \mathrm{a}=$ not active

Table 2. Total phenolic content of pranajiwa (Euchresta horsfieldii) methanolic extracts

\begin{tabular}{lc}
\hline Extracts & $\begin{array}{c}\text { Total phenolic content } \\
\text { (\%GAE/dry extract) }\end{array}$ \\
\hline Roots & $7.63 \pm 0.01^{\mathrm{a}}$ \\
Stems & $5.89 \pm 0.01^{\mathrm{c}}$ \\
Leaves & $6.03 \pm 0.09^{\mathrm{b}}$ \\
Fruits & $1.67 \pm 0.05^{\mathrm{e}}$ \\
Seeds & $4.09 \pm 0.11^{\mathrm{d}}$ \\
\hline Note: Data
\end{tabular}

Note: Data were expressed as mean \pm standard deviation. Different letters in the same column indicate significant differences $(p<0.05)$. GAE $=$ Gallic acid equivalent 


\section{ACKNOWLEDGMENTS}

We thank Dr. Rizna Triana Dewi and the Research Center for Chemistry, Indonesian Institute of Sciences (LIPI), for measuring alpha-glucosidase inhibitory activity. We also thank Analytical Chemistry Laboratory, Mataram University, Indonesia, for facilitating the UV spectrophotometer for antioxidant assay and Gipi Samawandana for his assistance during sample collection.

\section{REFERENCES}

Bahmani M, Golshahi H, Saki K, Kopaei MR, Delfan B, Mohammadi T. 2014. Medicinal plants and secondary metabolites for diabetes mellitus control. Asian Pac J Trop Dis 4: S687-S692.

Basma AA, Zakaria Z, Lactha YL, Sasidharan S. 2011. Antioxidant activity and phytochemical screening of the methanol extracts of Euphorbia hirta L. Asian Pac J Trop Med 5: 386-390.

Chanda S, Dave R. 2009. In vitro models for antioxidant activity evaluation and some medicinal plants possessing antioxidant properties: An overview. Afr J Mic Res 3: 981-996.

Cheng AYY and Josse RG. 2004. Intestinal absorption inhibitors for type 2 diabetes mellitus: prevention and treatment. Drug Discov Today: Ther Strateg 1 (2): 201-206.

Dewi RT, Tachibana S, Darmawan A. 2014. Effect on a-glucosidase inhibition and antioxidant activities of butyrolactone derivatives from Aspergillus terreus MC75. Med Chem Res 23: 454-460.

El-Haci IA, Bekkara FA, Mazari W, Gherib M. 2013. Phenolics content and antioxidant activity of some organic extracts of endemic medicinal plant Anabasis aretioides Coss. \& Moq. from Algerian Sahara. Pharmacogn J 5: 108-112.

Emami SA, Asili J, Mohagheghi Z, Hassanzadeh MK. 2007. Evid Based Compl Alternat Med 4 (3): 313-319.

Ghadyale V, Takalikar S, Haldavnekar V, Arvindekar A. 2011. Effective control of postprandial glucose level through inhibition of intestinal alpha-glucosidase by Cymbopogon martini (Roxb.). Evid Based Complement Alternat Med. 2012: 372909. DOI $10.1155 / 2012 / 372909$.

Gunawan IWG, Puspawati NM, Dewi NWRK, Parwata MOA. 2017 Effect of Euchresta horsfieldii Lesch Benn. leaf extract on increases enzyme activity of superoxide dismutase and glutathione peroxidase in rats with maximum physical activity. J Pharm Sci Res 9 (5): 578 582 .

Gurudeeban S, Satyavani K, Ramanathan T. 2012. Alpha-glucosidase inhibitory effect and enzyme kinetics of coastal medicinal plants. Bangladesh J Pharmacol 7: 186-191.

Ha H, Hwang I, Park JH, Lee HB. 2008. Role of reactive oxygen species in the pathogenesis of diabetic nephropathy. Diabetes Res Clin Pract 825: $542-545$.

Heyne, K. 1987. Tumbuhan Berguna Indonesia. Badan Litbang Kehutanan, Departemen Kehutanan Indonesia. Yayasan Sarana Wana Jaya, Jakarta. [Indonesian]
Jayaprakasha GK, Singh RP, Sakariah KK. 2001. Antioxidant activity of grape seed (Vitis vinifera) extracts on peroxidation models in vitro. Food Chem 73: 285-290.

Khalaf NA, Shakya AK, Al-Othman A, El-Agbar Z, Farah H. 2007. Antioxidant activity of some common plants. Turk J Biol 32: 51-55.

Kim JH, Kim D, Kim J, Hwang JK. 2011. Euchresta horsfieldii Benn. Activates peroxisome proliferator-activated receptor $\alpha$ and regulates expression of genes involved in fatty acid metabolism in human HepG2 cells. J Ethnopharmacol 133: 244-247.

Kloppenburgh-Versteegh J. 2006. Tanaman Berkhasiat Indonesia. IPB Press, Bogor. [Indonesian]

Lee SH, Li Y, Karadeniz F, Kim MM, Kim SK. 2009. $\alpha$-Glucosidase and $\alpha$-amylase inhibitory activities of Phloroglucinol derivatives from edible marine brown alga, Ecklonia cava. J Sci Food Agric 89: 155115558.

Mezit A, Meziti H, Boudiaf K, Mustapha B, Bouriche H. 2012. Polyphenolic profile and antioxidant activities of Nigella Sativa seed extract in vitro and in vivo. World Acad Sci Eng Technol 64: 24-32.

Mogea JP, Gandawidjaya D, Wiriadinata H, Nasution RE, Irawati. 2001. Tumbuhan Langka Indonesia. Pusat Penelitian dan Pengembangan Biologi - LIPI, Bogor. [Indonesian]

Noh H, Ha H. 2011. Reactive oxygen species and oxidative stress. Contrib Nephrol 170: 102-112.

Pham-Huy LA, He H, Pham-Huy C. 2008. Free radicals, antioxidants in disease and health. Intl J Biomed Sci 4 (2): 89-96.

Piao MJ, Kang KA, Zhang R, Ko DO, Wang ZH, Lee KH, Chang WY, Chae S, Jee Y, Shin T, Park JW, Lee NH, Hyun JW. 2009. Antioxidant Properties of 1,2,3,4,6-Penta-O-galloyl- $\beta$-D-glucose from Elaeocarpus sylvestris var. ellipticus. Food Chem 115: 412-418.

Prihantini AI, Tachibana S, Itoh K. 2014. Evaluation of antioxidant and $\alpha$ glucosidase inhibitory activities of some subtropical plants. Pak J Biol Sci 17 (10): 1106-1114.

Rice-Eans CA, Miller NJ, Paganga G. 1996. Structure-antioxidant relationships of flavonoids and phenolic acids. Free Radic Biol Med 20: 933-956.

Ruberto, G, Baratta MT. 2000. Antioxidant activity of selected essential oil components in two lipid model system. Food Chem 69: 167-174.

Sancheti S, Sancheti S, Bafna M, Seo SY. 2011. 2,4,6Trihydroxybenzaldehyde as a potent antidiabetic agent alleviates postprandial hyperglycemia in normal and diabetic rats. Med Chem Res 20: 1181-1187.

Sari KAI, Gunawan IWG, Putra KGD. 2015. Kapasitas antioksidan senyawa golongan triterpenoid pada daun pranajiwa (Euchresta horsfieldii Lesch Benn). Jurnal Kimia 9 (1): 61-66. [Indonesian]

Shibano M, Kakutani K, Taniguchi M, Yasuda M, Baba K. 2008. Antioxidant constituent in the dayflower (Commelina communis L.) and their $\alpha$-glucosidase inhibitory activity. J Nat Med 62: 349-353.

Singleton VL, Orthofer R, Raventos RML. 1999. Analysis of total phenols and other oxidation substrates and antioxidant by means of FolinCiocalteu reagent. Methods Enzymol 299: 152-178.

Tirta IG, Ardaka IM, Darma IDP. 2010. Studi fenologi dan senyawa kimia pronojiwo (Euchresta horsfieldii (Lesch.) Benn.). Bul Litro 21 (1): 28-36. [Indonesian]

Van de Laar FA, Lucassen PLBJ, Akkermans RP, Van de Lisdonk EH, Rutten GEHM, Van Weel C. 2005. Alpha-glucosidase inhibitors for type 2 diabetes mellitus (review). Cochrane Database Syst Rev 28 (1): 154-163. 